\title{
60 Years of Folia - Review and Comparison of Two General Journals in Our Field
}

\author{
Harm K. Schutte ${ }^{a}$ Jan G. Švec ${ }^{b}$ \\ ${ }^{a}$ Groningen Voice Research Laboratory, University of Groningen, Groningen, The Netherlands; \\ ${ }^{b}$ Department of Experimental Physics, Laboratory of Biophysics, Faculty of Science, Palacky University Olomouc, \\ Olomouc, Czech Republic
}

This issue of Folia Phoniatrica et Logopaedica marks the end of the 60th volume of the international scientific journal of the International Association of Logopedics and Phoniatrics (IALP). The IALP was founded in 1924, in the interbellum between the two world wars, on instigation of Emil Froeschels from Vienna and a few colleagues, Stern, Stein, Rothe and Trojan. International conferences were held in different places in Europe, which series was unfortunately interrupted by the Second World War. The last IALP international conference was held in Copenhagen in 1936, the first after-war conference was held 14 years later in Amsterdam in 1950.

In these 14 years several well-known colleagues had died but, fortunately, many of the leading European phoniatricians could escape to a safer place in the world (many were Jewish). The conference in Amsterdam was held in a joyful atmosphere, renewing acquaintance after the war. Many pre-war specialized journals in the field had ceased publication, so in effect by the end of the war no single specialized journal in the field was available to the clinicians. There was a clearly recognized need to provide some means whereby professionals working in the field of phoniatrics and logopedics could develop their interest, present research results, publish papers of scientific and practical importance and in this way communi- cate with each other, also across the borders. The interest in phoniatrics and logopedics was taken over by a rising second generation of medical doctors working in the field of phoniatrics. Against this background the journal Folia Phoniatrica was founded by Richard Luchsinger (Zürich), Miloslav Seeman (Prague), and Jean Tarneaud (Paris). The name Folia Phoniatrica did fit well in the trend of that after-war time. Many 'Folias' were founded, but not many survived until today. On initiative of the IALP the name was modified to Folia Phoniatrica et Logopaedica in 1994, but the Latin language was kept. Folia Phoniatrica et Logopaedica now exists 60 years and this is more than worth celebrating.

We will do this by a novelty in the history of Folia. For the first time an article, written by Jürgen Wendler, is accompanied by audio-visual illustrations. This article is a slightly modified version of an invited lecture presented at the 7th PanEuropean Voice Conference (PEVoC) in Groningen in 2007. This conference carried the motto '60 Years of Voice Research in Groningen', because Jw. van den Berg started the research on the production of vowels and the basis of human sound - the production of voice - in Groningen in 1947. Wendler's article concentrates on the phoniatricians that also showed a great interest in (semi)-professional singing.

\section{KARGER}

Fax +4161306 1234 E-Mail karger@karger.ch www.karger.com
(C) 2008 S. Karger AG, Basel

$1021-7762 / 08 / 0606-0273 \$ 24.50 / 0$

Accessible online at:

www.karger.com/fpl
Prof. Harm K. Schutte

Department of Biomedical Engineering

Faculty of Medical Sciences, University of Groningen

Ant Deusinglaan 1, NL-9713 AV Groningen (The Netherlands)

E-Mail harm.k.schutte@gmail.com 
The audio-visual files with historic illustrative material can be downloaded from the Karger website server (www.karger.com/doi/10.1159/000170076). Thanks to the generosity of Karger Publishing, all the readers can have access to see and hear our predecessors in the field.

In the first three to four decennia Folia took the lead in the field of communication disorders. In recent time more specialized journals have emerged, e.g. on aphasia, on language development, on voice, on stuttering, etc., but the publications and interest, in general, has hardly changed over the years. We, at this moment, expect a boost from the fact that our impact factor currently is about 1.4. This is especially of importance for the (West)European countries. Our journal has taken an active approach with regard to impact factor measures and we intend to keep this initiative to protect the field of phoniatrics and logopedics against blindly applied general criteria of scientific measures handicapping under-researched interdisciplinary fields [1].

However, how is the situation compared to other general journals in our field? The journal which has the most similar focus to Folia Phoniatrica et Logopaedica and is published in Europe is Logopedics-PhoniatricsVocology (LPV), which is now in the 32nd year of appearance, after several name changes. An obvious difference between these two journals is the rate of issuing: Folia appears 6 times a year, and LPV 4 times a year. Of course this has a direct influence on the number of articles in a volume. In Folia 42 articles were published in 2007, 3 more than in 2006. The total number over 2006 and 2007 is 81 articles. In 2006 and 2007 LPV published 44 articles. In table 1 a comparison is given between the two journals on the countries from which the articles originated. This table is based on the country of the first author. Accepted articles came from 26 countries in Folia and 17 countries in LPV. It might be that researchers from more than one country contributed to some of the published articles, but that is not reflected in table 1. It might be clear that LPV is more Scandinavia- and UKoriented, which appears to be a consequence of the fact that the origins of LPV are in the former Scandinavian Journal of Logopedics and Phoniatrics and the UK journal Voice. Folia is more broadly internationally oriented since it is an official journal of the world-encompassing IALP [1].

Another even more interesting issue is the contents of both journals. We categorized the contents following an easy concept. This is, of course, a personal choice and could be subject to criticism, but, in general, a slightly different approach in categorization would not change the
Table 1. Number of articles published in 2006-2007 per country of the first author

\begin{tabular}{|c|c|c|c|c|}
\hline \multirow[t]{2}{*}{ Country } & \multicolumn{2}{|c|}{$\begin{array}{l}\text { Folia Phoniatrica } \\
\text { et Logopaedica }\end{array}$} & \multicolumn{2}{|c|}{$\begin{array}{l}\text { Logopedics-Phoniatrics- } \\
\text { Vocology }\end{array}$} \\
\hline & articles & references & articles & references \\
\hline USA & 17 & {$[4,10-25]$} & 5 & {$[26-29]$} \\
\hline The Netherlands & 11 & {$[1,30-39]$} & 1 & {$[40]$} \\
\hline Germany & 8 & {$[41-48]$} & 3 & {$[49-51]$} \\
\hline Australia & 6 & {$[2,52-56]$} & 3 & {$[5,8,57]$} \\
\hline Belgium & 5 & {$[58-62]$} & - & \\
\hline Brazil & 4 & {$[63-66]$} & - & \\
\hline United Kingdom & 4 & {$[3,67-69]$} & 6 & {$[70-75]$} \\
\hline PR of China & 3 & {$[7,76,77]$} & - & \\
\hline Finland & 2 & {$[78,79]$} & 8 & {$[80-87]$} \\
\hline Greece & 2 & {$[88,89]$} & - & \\
\hline Japan & 2 & {$[90,91]$} & 1 & {$[92]$} \\
\hline Malta & 2 & {$[93,94]$} & - & \\
\hline Switzerland & 2 & {$[9,95]$} & 1 & {$[96]$} \\
\hline Canada & 1 & [97] & - & \\
\hline Egypt & 1 & [98] & - & \\
\hline France & 1 & [99] & 2 & {$[100,101]$} \\
\hline Ireland & 1 & [102] & 1 & {$[103]$} \\
\hline Italy & 1 & {$[104]$} & - & \\
\hline Jordan & 1 & {$[105]$} & - & \\
\hline Norway & 1 & [106] & 2 & {$[107,108]$} \\
\hline Poland & 1 & [109] & 1 & [110] \\
\hline Portugal & 1 & [111] & - & \\
\hline South Africa & 1 & {$[112]$} & - & \\
\hline Spain & 1 & [113] & - & \\
\hline Sweden & 1 & {$[114]$} & 5 & {$[6,115-118]$} \\
\hline Taiwan & 1 & [119] & - & \\
\hline Austria & - & & 1 & {$[120]$} \\
\hline Russia & - & & 1 & [121] \\
\hline Czech Republic & - & & 2 & {$[122,123]$} \\
\hline Turkey & - & & 1 & {$[124]$} \\
\hline Total & 81 & & 44 & \\
\hline
\end{tabular}

general picture. Table 2 shows the results of this categorization including the references to the articles in both journals. In Folia the articles are spread over more topics of phoniatrics and logopedics, whereas LPV publishes a larger percentage of articles on 'voice'.

Based on the information above, we may conclude that the 60-year-old journal Folia Phoniatrica et Logopaedica serves well as the general journal in the field of communication disorders. While in the past Folia was considered by some of our colleagues mainly a 'voice' journal, comparison with another European (general) journal like LPV makes it clear that this is not true anymore. 
Table 2. Distribution of articles published in 2006 and 2007 categorized after the topic

\begin{tabular}{|c|c|c|c|c|c|}
\hline \multirow[t]{2}{*}{ Field } & \multirow[t]{2}{*}{ Topic } & \multicolumn{2}{|c|}{ Folia Phoniatrica et Logopaedica } & \multicolumn{2}{|c|}{ Logopedics-Phoniatrics-Vocology } \\
\hline & & articles & references & articles & references \\
\hline \multirow[t]{5}{*}{ Voice } & assessment/evaluation & 14 & $\begin{array}{l}{[11,30-33,36,53,66,77-79,99,109,} \\
119]\end{array}$ & 11 & $\begin{array}{l}{[5,6,8,72,81,83,84,103,110,117,} \\
121]\end{array}$ \\
\hline & acoustics/singing & 1 & {$[19]$} & 9 & {$[49,57,70,75,80,82,87,100,101]$} \\
\hline & physiology/basic science & 9 & {$[14,21,35,37,42,46,76,106,111]$} & 9 & {$[26,50,51,74,85,96,120,122,123]$} \\
\hline & voice rehab/laryngectomy & 2 & {$[7,41]$} & 6 & {$[28,29,40,71,73,86]$} \\
\hline & laryngology & 5 & {$[22,56,64,65,67]$} & 1 & {$[115]$} \\
\hline \multirow[t]{4}{*}{ Speech } & articulation/dysarthria & 11 & {$[4,12,16,24,25,55,59,60,91,104,105]$} & 4 & {$[27,108,116,118]$} \\
\hline & education & 10 & {$[10,13,15,18,52,63,90,93,102,114]$} & 1 & {$[124]$} \\
\hline & stuttering & 3 & {$[38,58,68]$} & - & - \\
\hline & nasality & 4 & {$[9,17,44,62]$} & - & - \\
\hline Language & & 13 & $\begin{array}{l}{[2,3,20,23,48,54,61,69,89,94,97,98} \\
113]\end{array}$ & 1 & {$[107]$} \\
\hline Hearing & & 3 & {$[43,45,47]$} & 1 & {$[92]$} \\
\hline Swallowing & & 1 & [112] & - & - \\
\hline Book reviews & & 3 & {$[34,88,95]$} & - & - \\
\hline Editorial & & 2 & {$[1,39]$} & 1 & {$[125]$} \\
\hline Total & & 81 & & 44 & \\
\hline
\end{tabular}

\section{References}

1 Schutte HK, Svec JG: Reaction of Folia Phoniatrica et Logopaedica on the current trend of impact factor measures. Folia Phoniatr Logop 2007;59:281-285.

$\checkmark 2$ Dodd B: Evidence-based practice and speech-language pathology: strengths, weaknesses, opportunities and threats. Folia Phoniatr Logop 2007;59:118-129.

$\checkmark 3$ Fisher SE: Molecular windows into speech and language disorders. Folia Phoniatr Logop 2007;59:130-140.

$\checkmark 4$ Yorkston KM: The degenerative dysarthrias: a window into critical clinical and research issues. Folia Phoniatr Logop 2007;59:107117.

5 Baker J, Ben-Tovim DI, Butcher A, Esterman A, McLaughlin K: Development of a modified diagnostic classification system for voice disorders with inter-rater reliability study. Logoped Phoniatr Vocol 2007;32:99-112.

$\checkmark 6$ Holmberg EB, Ihre E, Södersten M: Phonetograms as a tool in the voice clinic: changes across voice therapy for patients with vocal fatigue. Logoped Phoniatr Vocol 2007;32: 113-127.

7 Liu HJ, Ng ML, Wan MX, Wang SP, Zhang Y: Effects of place of articulation and aspiration on voice onset time in Mandarin esophageal speech. Folia Phoniatr Logop 2007;59:147154.
8 Pasa G, Oates J, Dacakis G: The relative effectiveness of vocal hygiene training and vocal function exercises in preventing voice disorders in primary school teachers. Logoped Phoniatr Vocol 2007;32:128-140.

$\checkmark 9$ Vrticka K: Present-day importance of the velocardiofacial syndrome - to commemorate the late Prof. Eva Sedlackova, MD, on the 50th anniversary of her original publication. Folia Phoniatr Logop 2007;59:141-146.

$>10$ Battle DE: The education of speech-language pathologists in the United States of America. Folia Phoniatr Logop 2006;58:7-13.

11 Bunton K: Fundamental frequency as a perceptual cue for vowel identification in speakers with Parkinson's disease. Folia Phoniatr Logop 2006;58:323-339.

12 Chen Y: Production of tense-lax contrast by Mandarin speakers of English. Folia Phoniatr Logop 2006;58:240-249.

13 Cheng LRL: Global perspective of speech pathology education. Folia Phoniatr Logop 2006;58:5-6.

14 Deliyski DD, Shaw HS, Evans MK, Vesselinov R: Regression tree approach to studying factors influencing acoustic voice analysis. Folia Phoniatr Logop 2006;58:274-288.

15 Gallagher TM: US doctoral education: critical shortages and plans for reshaping the future. Folia Phoniatr Logop 2006;58:32-35.

-16 Hustad KC: Estimating the intelligibility of speakers with dysarthria. Folia Phoniatr Logop 2006;58:217-228.
17 Jones DL: Patterns of oral-nasal balance in normal speakers with and without cleft palate. Folia Phoniatr Logop 2006;58:383-391.

18 Logemann JA: Preparation of speech-language pathologists in the United States: the master's degree. Folia Phoniatr Logop 2006; 58:55-58.

19 Ng ML, Bailey RL: Acoustic changes related to laryngeal examination with a rigid telescope. Folia Phoniatr Logop 2006;58:353362 .

20 Smith AB, Robb MP: The influence of utterance position on children's production of lexical stress. Folia Phoniatr Logop 2006;58: 199-206.

21 Brown WS, Shrivastav R: Comfortable effort level in young children's speech. Folia Phoniatr Logop 2007;59:227-233.

22 Charpied GL: The pars interna/media anatomy and histology in the human larynx. Folia Phoniatr Logop 2007;59:241-249.

23 Hough MS: Incidence of word finding deficits in normal aging. Folia Phoniatr Logop 2007;59:10-19.

24 Hustad KC: Effects of speech stimuli and dysarthria severity on intelligibility scores and listener confidence ratings for speakers with cerebral palsy. Folia Phoniatr Logop 2007;59:306-317. 
25 Roy N, Mauszycki SC, Merrill RM, Gouse M, Smith ME: Toward improved differential diagnosis of adductor spasmodic dysphonia and muscle tension dysphonia. Folia Phoniatr Logop 2007;59:83-90.

-26 Kunduk M, Yan Y, McWhorter AJ, Bless D: Investigation of voice initiation and voice offset characteristics with high-speed digital imaging. Logoped Phoniatr Vocol 2006;31: 139-144.

27 Searl J, Evitts P, Davis WJ: Perceptual and acoustic evidence of speaker adaptation to a thin pseudopalate. Logoped Phoniatr Vocol 2006;31:107-116.

28 Titze IR, Laukkanen AM: Can vocal economy in phonation be increased with an artificially lengthened vocal tract? A computer modeling study. Logoped Phoniatr Vocol 2007;32:147-156.

-29 Evitts PM, Gabel R, Searl J: Listeners' perceptions of the personality of male alaryngeal speakers. Logoped Phoniatr Vocol 2007;32: 53-59.

-30 de Jong FI, Kooijman PG, Thomas G, Huinck WJ, Graamans K, Schutte HK: Epidemiology of voice problems in Dutch teachers. Folia Phoniatr Logop 2006;58:186-198.

- 31 Hakkesteegt MM, Wieringa MH, Gerritsma EJ, Feenstra L: Reproducibility of the Dutch version of the Voice Handicap Index. Folia Phoniatr Logop 2006;58:132-138.

- 32 Hakkesteegt MM, Brocaar MP, Wieringa $\mathrm{MH}$, Feenstra L: Influence of age and gender on the dysphonia severity index: a study of normative values. Folia Phoniatr Logop 2006;58:264-273.

- 33 Kooijman PG, de Jong FI, Thomas G, Huinck W, Donders R, Graamans K, Schutte HK: Risk factors for voice problems in teachers. Folia Phoniatr Logop 2006;58:159-174.

-34 Miller DG: Janice L. Chapman - Singing and Teaching Singing: A Holistic Approach to Classical Voice (book review). Folia Phoniatr Logop 2006;58:303-304

- 35 Thomas G, De Jong FICR, Cremers CWRJ, Kooijman PGC: Prevalence of voice complaints, risk factors and impact of voice problems in female student teachers. Folia Phoniatr Logop 2006;58:65-84.

- 36 Thomas G, de Jong FI, Kooijman PG, Cremers CW: Utility of the Type D Scale 16 and Voice Handicap Index to assist voice care in student teachers and teachers. Folia Phoniatr Logop 2006;58:250-263.

- 37 Thomas G, de Jong FI, Kooijman PG, Donders AR, Cremers CW: Voice complaints, risk factors for voice problems and history of voice problems in relation to puberty in female student teachers. Folia Phoniatr Logop 2006;58:305-322.

38 Huinck W, Rietveld T: The validity of a simple outcome measure to assess stuttering therapy. Folia Phoniatr Logop 2007;59:9199.

39 Svec JG, Behlau M: April 16th: The World Voice Day. Folia Phoniatr Logop 2007;59: 53-54.
40 Jongmans P, Hilgers FJ, Pols LC, van AsBrooks CJ: The intelligibility of tracheoesophageal speech, with an emphasis on the voiced-voiceless distinction. Logoped Phoniatr Vocol 2006;31:172-181.

41 Dahl R, Witt G: Analyse von Stimmparametern nach konservativer Behandlung von Larynxparesen mit konventioneller Stimmübung oder neuromuskulärer elektrophonatorischer Stimulation. Folia Phoniatr Logop 2006;58:415-426.

42 Hess MM, Mueller F, Kobler JB, Zeitels SM Goodyer E: Measurements of vocal fold elasticity using the linear skin rheometer. Folia Phoniatr Logop 2006;58:207-216.

43 Kummer P, Burger M, Schuster M, Rosanowski F, Eysholdt U, Hoppe U: Cortical auditory evoked potentials to acoustic changes in speech stimuli in children. Folia Phoniatr Logop 2007;59:273-280.

44 Mueller K, Neuber B, Schelhorn-Neise P, Schumann D: Diagnostic value of nasometry - representative study of patients with cleft palate and normal subjects. Folia Phoniatr Logop 2007;59:219-226.

45 Neumann K, Gross M, Böttcher P, Euler HA Spormann-Lagodzinski M, Polzer M: Effectiveness and efficiency of a universal newborn hearing screening in Germany. Folia Phoniatr Logop 2006;58:440-455.

46 Rasp O, LohschellerJ, Doellinger M, Eysholdt U, Hoppe U: The pitch rise paradigm: a new task for real-time endoscopy of non-stationary phonation. Folia Phoniatr Logop 2006; 58:175-185.

47 Reeh M, Kiese-Himmel C: Veränderungsmessung der Fähigkeit zur lautsprachlichen Analogiebildung schallempfindungsgestörter Kinder. Folia Phoniatr Logop 2007; 59:65-73.

48 Wink M, Rosanowski F, Hoppe U, Eysholdt $\mathrm{U}$, Grassel E: Subjective burden in mothers of speech-impaired children. Folia Phoniatr Logop 2007;59:268-272.

49 Andreas T: The influence of tonal movement and vowel quality on intelligibility in singing. Logoped Phoniatr Vocol 2006;31:17-22.

50 Dresel C, Mergell P, Hoppe U, Eysholdt U: An asymmetric smooth contour two-mass model for recurrent laryngeal nerve paralysis. Logoped Phoniatr Vocol 2006;31:61-75.

51 Winkler R, Sendlmeier W: EGG open quotient in aging voices: changes with increasing chronological age and its perception. Logoped Phoniatr Vocol 2006;31:51-56.

52 Ferguson A: Competency-based occupational standards: influences on Australian speech pathology education. Folia Phoniatr Logop 2006;58:23-31.

53 Walsh R, Behlau M: A new perspective on terminology. Folia Phoniatr Logop 2006;58: 380-381.

54 Docking KM, Murdoch BE, Suppiah R: The impact of a cerebellar tumour on language function in childhood. Folia Phoniatr Logop 2007;59:190-200
55 Murdoch BE, Whelan BM: Language disorders subsequent to left cerebellar lesions: a case for bilateral cerebellar involvement in language? Folia Phoniatr Logop 2007;59: 184-189.

56 Vertigan AE, Theodoros DG, Winkworth AL, Gibson PG: Perceptual voice characteristics in chronic cough and paradoxical vocal fold movement. Folia Phoniatr Logop 2007; 59:256-267.

57 Gullaer I, Walker R, Badin P, Lamalle L: Image, imagination, and reality: on effectiveness of introductory work with vocalists. Logoped Phoniatr Vocol 2006;31:89-96.

-58 Van Borsel J, Moeyaert J, Mostaert C, Rosseel R, Van Loo E, Van Renterghem T: Prevalence of stuttering in regular and special school populations in Belgium based on teacher perceptions. Folia Phoniatr Logop 2006;58: 289-302.

59 De Smet HJ, Baillieux H, De Deyn PP, Mariën P, Paquier P: The cerebellum and language: the story so far. Folia Phoniatr Logop 2007; 59:165-170.

60 Mariën P, Verhoeven J: Cerebellar involvement in motor speech planning: some further evidence from foreign accent syndrome. Folia Phoniatr Logop 2007;59:210-217.

61 Paquier PF: The cerebellum and language (editorial). Folia Phoniatr Logop 2007;59: 163-164.

62 Van Lierde KM, Wuyts FL, Bonte K, Van CP: The nasality severity index: an objective measure of hypernasality based on a multiparameter approach. A pilot study. Folia Phoniatr Logop 2007;59:31-38.

63 Behlau M, Gasparini G: Education of speechlanguage pathologists and audiologists in Brazil. Folia Phoniatr Logop 2006;58:14-22.

64 Pontes P, Yamasaki R, Behlau M: Morphological and functional aspects of the senile larynx. Folia Phoniatr Logop 2006;58:151158.

65 Ruiz DM, Pontes P, Behlau M, Richieri-Costa A: Laryngeal microweb and vocal nodules: clinical study in a Brazilian population. Folia Phoniatr Logop 2006;58:392-399.

66 Behlau M, Hogikyan ND, Gasparini G: Quality of life and voice: study of a Brazilian population using the voice-related quality of life measure. Folia Phoniatr Logop 2007;59: 286-296.

67 Al-Yousuf A, Jain A, Parker AJ: Postthyroplasty implant extrusion. Folia Phoniatr Logop 2006;58:139-142.

68 Howell P: The effects of gated speech on the fluency of speakers who stutter. Folia Phoniatr Logop 2007;59:250-255.

-69 Dockrell JE, Messer D: Language profiles and naming in children with word finding difficulties. Folia Phoniatr Logop 2007;59: 318-323.

70 Fourcin A: Discussant response to 'Mirroring the voice from Garcia to the present day: some insights into singing voice registers'. Logoped Phoniatr Vocol 2006;31:15-16. 
71 Fulljames N, Harris S: Voice outcome measures: correlations with patients' assessment of their condition and the effectiveness of voice therapy. Logoped Phoniatr Vocol 2006; 31:23-35.

72 Carding P: Occupational voice disorders: is there a firm case for industrial injuries disablement benefit? Logoped Phoniatr Vocol 2007;32:47-48.

73 Snelling JD, Price T, Montgomery PQ, Blagnys BL: How we do it: secondary tracheoesophageal puncture under local anaesthetic, using a trans-nasal flexible laryngooesophagoscope (TNFLO). Logoped Phoniatr Vocol 2007;32:80-82.

74 Davies J, Anderson S, Huchison L, Stewart $\mathrm{G}$ : Interactions between voice clinics and singing teachers: a report on the British Voice Association questionnaire to voice clinics in the UK. Logoped Phoniatr Vocol 2007;32:83-86.

75 Howard DM: Equal or non-equal temperament in a capella SATB singing. Logoped Phoniatr Vocol 2007;32:87-94.

76 Liu H, Wan M, Ng ML, Wang S, Lu C: Tonal perceptions in normal laryngeal, esophageal, and electrolaryngeal speech of Mandarin. Folia Phoniatr Logop 2006;58:340-352.

-77 Ma EP, Yiu EM: Scaling voice activity limitation and participation restriction in dysphonic individuals. Folia Phoniatr Logop 2007;59:74-82.

78 Alku P, Story B, Airas M: Estimation of the voice source from speech pressure signals: evaluation of an inverse filtering technique using physical modelling of voice production. Folia Phoniatr Logop 2006;58:102113.

-79 Laukkanen AM, Kankare E: Vocal loadingrelated changes in male teachers' voices investigated before and after a working day. Folia Phoniatr Logop 2006;58:229-239.

$>80$ Toivanen J, Waaramaa T, Alku P, Laukkanen AM, Seppänen T, Väyrynen E, Airas M: Emotions in [a]: a perceptual and acoustic study. Logoped Phoniatr Vocol 2006;31:4348.

-81 Lehto L, Laaksonen L, Vilkman E, Alku P: Occupational voice complaints and objective acoustic measurements: do they correlate? Logoped Phoniatr Vocol 2006;31:147152.

82 Björkner E, Sundberg J, Alku P: Subglottal pressure and normalized amplitude quotient variation in classically trained baritone singers. Logoped Phoniatr Vocol 2006;31:157165.

-83 Smolander S, Huttunen K: Voice problems experienced by Finnish comprehensive school teachers and realization of occupational health care. Logoped Phoniatr Vocol 2006;31:166-171.
84 Sukanen O, Sihvo M, Rorarius E, Lehtihalmes M, Autio V, Kleemola L: Voice Activity and Participation Profile (VAPP) in assessing the effects of voice disorders on patients quality of life: validity and reliability of the Finnish version of VAPP. Logoped Phoniatr Vocol 2007;32:3-8.

85 Laukkanen AM, Pulakka H, Alku P, Vilkman E, Hertegård S, Lindestad PA, Larsson $\mathrm{H}$, Granqvist S: High-speed registration of phonation-related glottal area variation during artificial lengthening of the vocal tract. Logoped Phoniatr Vocol 2007;32:157-164.

86 Simberg S, Laine A: The resonance tube method in voice therapy: description and practical implementations. Logoped Phoniatr Vocol 2007;32:165-170.

87 Waaramaa T, Alku P, Laukkanen AM: The role of F3 in the vocal expression of emotions. Logoped Phoniatr Vocol 2006;31:153156.

88 Papathanasiou I: Book review: occupational voice loss. Folia Phoniatr Logop 2007;59: 100-101.

89 Vlachos F, Papathanasiou I, Andreou G: Cerebellum and reading. Folia Phoniatr Logop 2007;59:177-183.

90 Iitaka K: Issues of Japanese speech therapy education considering the 1995 guidelines of International Association of Logopedics and Phoniatrics (IALP). Folia Phoniatr Logop 2006;58:41-47.

91 Nishio M, Niimi S: Comparison of speaking rate, articulation rate and alternating motion rate in dysarthric speakers. Folia Phoniatr Logop 2006;58:114-131.

-92 Nakamura H, Gilbert H, Robb M: A comparative study of vocal fundamental frequency in the speech of Japanese and American hearing-impaired children. Logoped Phoniatr Vocol 2007;32:17-22.

93 Grech H: Education in logopaedics in the Maltese Islands. Folia Phoniatr Logop 2006; 58:36-40.

94 Gatt D: Establishing the concurrent validity of a vocabulary checklist for young Maltese children. Folia Phoniatr Logop 2007;59:297305.

95 Muller A, Schutte HK: Gerhard Böhme, Manfred Gross - Stroboscopy (book review). Folia Phoniatr Logop 2006;58:143.

-96 Menzer F, Buchli J, Howard DM, Ijspeert AJ Nonlinear modelling of double and triple period pitch breaks in vocal fold vibration. Logoped Phoniatr Vocol 2006;31:36-42.

$\$ 97$ Walter N, Joanette Y: The unnoticed contributions of the cerebellum to language. Folia Phoniatr Logop 2007;59:171-176.

98 Saleh M, Shoeib R, Hegazi M, Ali P: Early phonological development in Arabic Egyptian children: 12-30 months. Folia Phoniatr Logop 2007;59:234-240.
99 Yu P, Garrel R, Nicollas R, Ouaknine M, Giovanni A: Objective voice analysis in dysphonic patients: new data including nonlinear measurements. Folia Phoniatr Logop 2007;59:20-30.

100 Henrich N: Mirroring the voice from Garcia to the present day: some insights into singing voice registers. Logoped Phoniatr Vocol 2006;31:3-14.

101 Henrich N, Kiek M, Smith J, Wolfe J: Resonance strategies used in Bulgarian women's singing style: a pilot study. Logoped Phoniatr Vocol 2007;32:171-177.

102 Leahy MM, Dodd BJ, Walsh IP, Murphy K: Education for practice in the UK and Ireland: implementing problem-based learning. Folia Phoniatr Logop 2006;58:48-54.

103 Murphy PJ: Spectral noise estimation in the evaluation of pathological voice. Logoped Phoniatr Vocol 2006;31:182-189.

104 Tavano A, Fabbro F, Borgatti R: Language and social communication in children with cerebellar dysgenesis. Folia Phoniatr Logop 2007;59:201-209.

105 Hamdan JM, Amayreh MM: Consonant profile of Arabic-speaking school-age children in Jordan. Folia Phoniatr Logop 2007; 59:55-64.

106 Pettersen V: Preliminary findings on the classical singer's use of the pectoralis major muscle. Folia Phoniatr Logop 2006;58:427439.

107 Lind M: Prosodic contextualization of minimal responses to yes/no-questions in aphasic talk-in-interaction: a descriptive single-case study of a Norwegian aphasic speaker. Logoped Phoniatr Vocol 2007;32: 9-16.

108 Helland WA, Heimann M: Assessment of pragmatic language impairment in children referred to psychiatric services: a pilot study of the Children's Communication Checklist in a Norwegian sample. Logoped Phoniatr Vocol 2007;32:23-30.

109 Sliwinska-Kowalska M, Niebudek-Bogusz E, Fiszer M, Los-Spychalska T, Kotylo P, Sznurowska-Przygocka B, Modrzewska M: The prevalence and risk factors for occupational voice disorders in teachers. Folia Phoniatr Logop 2006;58:85-101.

110 Niebudek-Bogusz E, Fiszer M, Kotylo P, Sliwinska-Kowalska M: Diagnostic value of voice acoustic analysis in assessment of occupational voice pathologies in teachers. Logoped Phoniatr Vocol 2006;31:100-106.

111 Mendes AP, Brown WS, Sapienza C, Rothman HB: Effects of vocal training on respiratory kinematics during singing tasks. Folia Phoniatr Logop 2006;58:363-377.

112 Bladon KL, Ross E: Swallowing difficulties reported by adults infected with HIV/AIDS attending a hospital outpatient clinic in Gauteng, South Africa. Folia Phoniatr Logop 2007;59:39-52. 
113 Aguilar-Mediavilla E, Serra-Raventos M: Phonological profile of Spanish-Catalan children with specific language impairment at age 4: are there any changes over time? Folia Phoniatr Logop 2006;58:400414.

114 Söderpalm E: Education of speech-language pathologists around the world: the Scandinavian experience. Folia Phoniatr Logop 2006;58:59-63.

115 Ylitalo R: Helicobacter pylori infection and its correlation to extraesophageal and esophageal reflux in contact granuloma patients. Logoped Phoniatr Vocol 2006;31: 57-60.

116 Schalling E, Hammarberg B, Hartelius L: Perceptual and acoustic analysis of speech in individuals with spinocerebellar ataxia (SCA). Logoped Phoniatr Vocol 2007;32: 31-46.
117 Aronsson C, Bohman M, Ternström S, Södersten M: Loud voice during environmental noise exposure in patients with vocal nodules. Logoped Phoniatr Vocol 2007; 32:60-70.

118 Lundeborg I, McAllister A: Treatment with a combination of intra-oral sensory stimulation and electropalatography in a child with severe developmental dyspraxia. Logoped Phoniatr Vocol 2007;32:71-79.

119 Chen SH: Sex differences in frequency and intensity in reading and voice range profiles for Taiwanese adult speakers. Folia Phoniatr Logop 2007;59:1-9.

120 Herbst C, Ternström S: A comparison of different methods to measure the EGG contact quotient. Logoped Phoniatr Vocol 2006;31:126-138.
121 Chernobelsky SI: The treatment and results of voice therapy amongst professional classical singers with vocal fold nodules. Logoped Phoniatr Vocol 2007;32:178-184.

122 Svancara P, Horacek J, Vokral J, Cerny L: Computational modelling of effect of tonsillectomy on voice production. Logoped Phoniatr Vocol 2006;31:117-125.

123 Horácek J, Laukkanen AM, Sidlof P: Estimation of impact stress using an aeroelastic model of voice production. Logoped Phoniatr Vocol 2007;32:185-192.

124 Topbas S: A Turkish perspective on communication disorders. Logoped Phoniatr Vocol 2006;31:76-88.

125 Titze IR: Editorial comments. Logoped Phoniatr Vocol 2007;32:146. 